\title{
Physical Fitness of Student at the Junior High School
}

\author{
*Berto Apriyano \\ Department of Physical Education \\ Universitas Negeri Padang \\ Padang, Indonesia \\ apriyano.b@graduate.utm.my
}

\author{
Zainal Abidin Zainuddin, Asha Hasnimy Mohd Hashim \\ School of Education \\ Faculty of Social Science Humanities \\ Johor, Malaysia \\ p-zainal@utm.my
}

\begin{abstract}
Objective. The main objectives and research questions of this review include the relationship between factors related to the fitness level of students. For the analysis phase to extract the required information and describe it in the form of a framework, then analyze the quality of each article obtained to answer the questions in this review. Methods. This review article aims to identify the level of physical fitness of students. This review will consist of a systematic review and review of studies conducted on the level of physical fitness of students at the junior high school level. In this review article, 12 related articles will be published from 2011 to 2019 . Of the entire article used must have the same criteria and keywords as the current discussion of researchers, namely physical fitness for junior high schools in Indonesia. Conclusions. The results showed that the level of physical fitness of students in modern learning from some changes in the learning curriculum can still be said to be unsatisfactory because Physical Education learning does not focus on the level of physical fitness but only on knowledge. This article is also used as a recommendation for further studies on Physical Education learning to develop and update learning methods or some form of training that can be used to improve students' physical fitness, especially at the junior high level. To advance the education sector in the 21 st century by jointly realizing the industrial revolution 4.0.
\end{abstract}

\section{Keywords-Physical fitness, Junior high school}

\section{INTRODUCTION}

Education with various problems is an interesting topic to talk about. This is not only because education is a human need, but education also directly determines the quality of human resource development.

The education system in Indonesia underwent many changes to improve and improve the process of learning and learning in Education. These changes have implications for curriculum improvement, strengthening teaching methods and techniques, introducing programs and increasing teacher professionalism.

The Law on the Indonesian Education System in CHAPTER II Article 3 of the Law of the Republic of Indonesia number 20 of 2003 reads: "National education functions to develop capabilities and shape the character and civilization of a dignified nation in the framework of the intellectual life of the nation, aiming at developing the potential of students to become human beings who believe and fear God Almighty, noble, healthy, knowledgeable, creative, independent and be a democratic and responsible citizen ".

To achieve the above educational objectives, the school as a formal education institution is an official place in which the entire process of shaping human character. The school is not only a gathering place for teachers and students, but it is a complex and complex system. Through the Education process, it is expected to develop the potential that exists in itself to meet the needs of his life, society and country, now and in the future.

The basics for improving the quality of education are sought to shape the profile of Indonesians who are provided intellectually, mentally, physically and spiritually to face challenges in the future. To achieve the goal of national education for junior high schools (SMP) as part of the formal education system, carry out learning activities in a compulsory subject or local content. One of the subjects in junior high school (SMP) is physical education in physical sports (Penjasorkes).

Based on the Law of the Republic of Indonesia number 3 of 2005 concerning the national sports system in CHAPTER I General Provisions article 1 number 11 which reads: "Sports education is physical education and sports carried out as part of an organized and continuing education process to obtain knowledge, personality, skills, health and physical fitness. "

Based on the Penjasorkes learning foundation above it can be said that the development of aspects of movement skills, movement knowledge and attitudes are the three main components in the implementation of learning. The school is required or has the responsibility to form healthy students, both physically and spiritually. Therefore, physical education in schools needs to be developed so that students are not only physically and spiritually healthy, but more than that students can channel and develop the interests and talents of each sport to him.

In general, Penjasorkes curriculum organizational structure is based on the unity of theoretical science and physical training as well as the game and tactics in winning sports competitions. Various parties need to pay serious attention to physical fitness among students. This is because physical fitness is a determining factor in the success of students in mastering the material, practice and support in other learning. 
However, with 3 hours a week devoted to Education Curriculum 13 (K13) for Physical Education subjects in one period every week it was felt to be not optimal

- The research team's object

Identify the physical fitness of students in junior high school.

- Research team questions

What level of physical fitness of students in junior high school?

\section{METHODOLOGY}

- Research team procedures

The research team has made a flow phase below that describes the review protocol used to carry out a systematic review of the physical fitness level of students and specifically at the junior high school level. This review was conducted in order to narrow the search space so that it is easier to apply according to a predetermined theme. It consists of three main phases namely article selection, analysis and finally a synthesis of findings.

In choosing an article based on the main title of the article whether it is in line with the main topic in this discussion is the level of physical fitness of students in junior high school. Based on this main topic, various keywords are used to search for information in the form of articles and research team reports. Then, articles will be collected and selected based on the main topic criteria by reading abstracts to identify whether the research team is in accordance with the research team's needs (Naylor et al., 2015).

The next step is to analyze the article by downloading or copying an article that has a full paper. The articles are then studied and relevant information entered into tables to be grouped. This information is then compared if there are similarities and differences that must be identified. Then all information related to the main topic is put together to facilitate understanding. The quality of the research team was then analyzed using an article quality assessment rubric in which the research team reviewed the quality of the research team based on various elements of the research team such as the title and abstract, objectives, hypotheses, methods used, findings, discussions, conclusions, and reference formats.

Information obtained from several articles based on the selection above is then summarized and combined so that it can be put together in the same main topic. Articles of the findings are explained according to their respective uses.

\section{- Eligibility Criteria}

The eligibility criteria are based on the objectives and scope of the research team as follows; Specific topics studied were the level of physical fitness of students in junior high school, the research team identified what factors could support the level of physical fitness, looked at the relationship that influenced and how the effect of physical fitness on student learning outcomes in school. Articles that do not meet the criteria listed above will not be analyzed; however, it will not be discarded because there may be useful information in articles that are relevant to the field of the research team.
- Databases and other sources of information used to identify relevant studies

The database used is a discussion of articles related to physical fitness level, either as journal articles or proceedings and articles from mass media.

\section{- Search Strategy}

Use a number of specialized journals that discuss the level of physical fitness, both journals, and articles, usually using a standard search, i.e. using Google Scholar or some available open journals that discuss the level of junior high school (SMP) specifically in Indonesia.

- Study selection process

The selection of articles is based on the eligibility criteria that fit the research team's goals and questions. The selection of physical fitness level as a study will be selected for this research team, the research team is interested to look deeper into the relationship and find out how it has contributed through several research teams that have been conducted on the level of physical fitness in students. Because with the review of this research team's article it is hoped that it can provide information for sports teachers as well as other subject teachers as well as parents / guardians of students especially for the research team in an effort to find out how the physical fitness level of students in junior high school and find out what factors that influence it and find solutions for how to improve and enhance it. The selection process starts with a glance at the title of the article and abstract of the article that meets the eligibility criteria. Furthermore, once considered to meet the requirements, the full-text article downloaded and studied in accordance with the objectives and the research team question of this research team.

- Data Extraction Process

The data extraction process involves extracting information from the article. In some articles or journals that study the data processing, this research team uses a quantitative research method descriptive team compared between articles where similarities and differences between articles are identified. Descriptive data analysis findings were studied according to the research team question and then summarized briefly to draw conclusions and understanding.

- The information will be drawn from the study included

What is the process of this research team, where the research team will be doing is about the level of physical fitness of students in junior high school and see how the process of data collection and how the results.

- Methods for assessing the quality of individual studies

The articles were assessed individually based on the suitability of the main topic, the research team's objectives and the research team's results. The assessment is done by taking into account several supporting factors of the main topic. then compiled and summarized into one group and groups that are not appropriate will be given a record of why and how it is not in line with the main topics conducted by the research team. 


\section{RESULT}

- Study selection process

The process of selecting this article, we selected articles that fit the topic of physical fitness, especially among junior high school students. From the various results, we selected articles that had the desired portion such as the research team gap, the research team's goals, and the desired results. Selection of articles only originating from Indonesia for suitability in data collection using TKJI and making a comparison of the results of the level of physical fitness in each area found in the existing article. The article sought is an article that has a high level of confidence in terms of the determinants of the results so that it reaches several factors that know how the level of physical fitness and what other influencing factors. Our relevance to the topic is very important, we pay attention because this is the result of the preparation of new articles to be written and is the basis for making further research studies for researchers.

Initial search for relevant articles and then select articles according to eligibility criteria. Articles were obtained from various sources, namely Google Scholar and online journals in Indonesia. Keywords used and search results obtained. It can be concluded that the use of various keywords will result in a more varied number of searches and articles. But he uses words of physical fitness level and the addition of junior high school students as keywords in searching for this article.

- List of excluded studies and reasons for their exclusion

In this article found quite a lot of articles that discuss the level of physical fitness, but in this case, the researcher will only focus on the junior high school level. With the existence of other variables that affect the level of physical fitness so researchers will see which factors really influence or not through the abstract and full paper of the article.

- Assessment of the quality of individual studies

Each article included in the review table has a quality that matches the desired topic. The included article has conducted research on physical fitness. In addition, the article is included in the review table which examines the relationship of physical fitness level with other factors such as school sports infrastructure, student motivation, nutritional level, self-concept, and school learning outcomes. So that all articles found from various universities in Indonesia can conclude that the level of physical fitness has a very positive impact on improving the quality of learning and learning. However, applications that have been made in the teaching and learning process in schools in research observations show very related, contributing and related, but have not been noticed specifically by junior high schools in general.
Table 1. Article Review

\begin{tabular}{|c|c|c|c|c|}
\hline No & $\begin{array}{c}\text { Author's } \\
\text { name \& } \\
\text { years }\end{array}$ & Title & Methodolgy & Result \\
\hline 1 & $\begin{array}{l}\text { (Annas, } \\
\text { 2011) }\end{array}$ & $\begin{array}{l}\text { Hubungan } \\
\text { Kesegaran } \\
\text { Jasmani, } \\
\text { Hemoglobin, } \\
\text { Status Gizi, } \\
\text { Dan Makan } \\
\text { Pagi } \\
\text { Terhadap } \\
\text { Prestasi } \\
\text { Belajar }\end{array}$ & $\begin{array}{l}\text { analytic } \\
\text { survey with } \\
\text { cross- } \\
\text { sectional } \\
\text { approach }\end{array}$ & $\begin{array}{l}\text { (1) there is no } \\
\text { significant } \\
\text { relationship } \\
\text { between physical } \\
\text { fitness level and } \\
\text { learning } \\
\text { achievement, (2) } \\
\text { there is a } \\
\text { significant } \\
\text { relationship } \\
\text { between } \\
\text { hemoglobin status } \\
\text { and learning } \\
\text { achievement, (3) } \\
\text { there is no } \\
\text { significant } \\
\text { relationship } \\
\text { between } \\
\text { nutritional status } \\
\text { and learning } \\
\text { achievement, (4) } \\
\text { there is a } \\
\text { relationship which } \\
\text { means the habit of } \\
\text { having breakfast } \\
\text { with the learning } \\
\text { achievement of the } \\
\text { eighth grade } \\
\text { students of MTs } \\
\text { Al Asror, Gunung } \\
\text { Pati Subdistrict, } \\
\text { Semarang City }\end{array}$ \\
\hline 2 & $\begin{array}{l}\text { (Widodo \& } \\
\text { Kusnanik, } \\
\text { 2013) }\end{array}$ & $\begin{array}{l}\text { Tingkat } \\
\text { Kesegaran } \\
\text { Jasmani pada } \\
\text { Siswa SMP } \\
\text { Negeri } 2 \\
\text { Krembung } \\
\text { dan SMP } \\
\text { Negeri } 2 \\
\text { Sidoarjo } \\
\end{array}$ & $\begin{array}{l}\text { Descriptive } \\
\text { analytical } \\
\text { research } \\
\text { methods }\end{array}$ & $\begin{array}{l}\text { the results } \\
\text { obtained are only } \\
\text { carried out the } \\
\text { translation of data, } \\
\text { without further } \\
\text { explanation. }\end{array}$ \\
\hline 3 & $\begin{array}{l}\text { (Yudi } \\
\text { Irianto \& } \\
\text { Nurhayati, } \\
\text { 2013) }\end{array}$ & $\begin{array}{l}\text { Hubungan } \\
\text { Status Gizi } \\
\text { dan Aktivitas } \\
\text { Olahraga } \\
\text { dengan } \\
\text { Tingkat } \\
\text { Kebugaran } \\
\text { Jasmani } \\
\text { (Studi pada } \\
\text { Siswa Kelas } \\
\text { VIII SMP } \\
\text { Negeri 1 } \\
\text { Kediri) }\end{array}$ & $\begin{array}{l}\text { Non- } \\
\text { experimental } \\
\text { quantitative } \\
\text { research } \\
\text { with } \\
\text { correlational } \\
\text { designs }\end{array}$ & $\begin{array}{l}\text { there is no } \\
\text { significant } \\
\text { relationship } \\
\text { between } \\
\text { nutritional status } \\
\text { and sports } \\
\text { activities with } \\
\text { physical fitness } \\
\text { level, but there is a } \\
\text { relationship } \\
\text { between } \\
\text { nutritional status } \\
\text { with physical } \\
\text { fitness level with a } \\
\text { contribution of } \\
42.5 \%\end{array}$ \\
\hline 4 & $\begin{array}{l}\text { (Soewito, } \\
\text { 2014) }\end{array}$ & $\begin{array}{l}\text { Pengaruh } \\
\text { Metode } \\
\text { Circuit } \\
\text { Training } \\
\text { Terhadap } \\
\text { Kebugaran } \\
\text { Jasmani } \\
\text { Peserta Didik } \\
\text { Kelas VII } \\
\text { SMP Negeri } 1 \\
\text { Jepon, } \\
\text { Kabupaten } \\
\text { Blora }\end{array}$ & $\begin{array}{l}\text { quasi- } \\
\text { experimental } \\
\text { research } \\
\text { with one- } \\
\text { group } \\
\text { pretest- } \\
\text { posttest } \\
\text { design } \\
\text { technique }\end{array}$ & $\begin{array}{l}\text { there is a } \\
\text { significant } \\
\text { influence of circuit } \\
\text { training methods } \\
\text { on the level of } \\
\text { physical fitness on } \\
\text { students }\end{array}$ \\
\hline
\end{tabular}




\begin{tabular}{|c|c|c|c|c|}
\hline 5 & $\begin{array}{l}\text { (Sulistiono, } \\
\text { 2014) }\end{array}$ & $\begin{array}{l}\text { Kebugaran } \\
\text { Jasmani } \\
\text { Siswa } \\
\text { Pendidikan } \\
\text { Dasar dan } \\
\text { Menengah di } \\
\text { Jawa Barat }\end{array}$ & $\begin{array}{l}\text { quantitative } \\
\text { research } \\
\text { with cross- } \\
\text { sectional } \\
\text { technique }\end{array}$ & $\begin{array}{l}\text { The level of } \\
\text { fitness of students } \\
\text { is not entirely in } \\
\text { good condition. } \\
\text { Only } 11.88 \\
\text { percent is good, } \\
42.27 \text { percent is } \\
\text { low, and } 45.86 \\
\text { percent is } \\
\text { moderate at the } \\
\text { elementary level. } \\
\text { Furthermore } 9.50 \\
\text { percent is good, } \\
36.87 \text { percent is } \\
\text { low, and } 53.63 \\
\text { percent is at the } \\
\text { junior high level. } \\
\text { Then } 46.11 \\
\text { percent is low, } \\
10.56 \text { percent is } \\
\text { good, and } 43.33 \\
\text { percent is at the } \\
\text { high school level. }\end{array}$ \\
\hline 6 & $\begin{array}{l}\text { (Julianto, } \\
2016)\end{array}$ & $\begin{array}{l}\text { Upaya } \\
\text { Meningkatkan } \\
\text { Kebugaran } \\
\text { Jasmani } \\
\text { Melalui } \\
\text { Sirkuit } \\
\text { Training Kids } \\
\text { pada Siswa }\end{array}$ & $\begin{array}{l}\text { classroom } \\
\text { action } \\
\text { research } \\
\text { methods }\end{array}$ & $\begin{array}{l}\text { In cycle } 1 \text { an } \\
\text { increase of } 58.54 \\
\text { percent from the } \\
\text { previous result } \\
\text { was } 54 \text { percent so } \\
\text { there was an } \\
\text { increase of } 4.54 \\
\text { percent from the } \\
\text { pre cycle. } \\
\text { Increased mastery } \\
\text { learning reached } \\
25 \text { students or } \\
76.67 \text { percent and } \\
\text { the remaining } 5 \\
\text { students or } 23.33 \\
\text { percent were } \\
\text { declared } \\
\text { incomplete or } \\
\text { lacking fitness. }\end{array}$ \\
\hline 7 & $\begin{array}{l}\text { (Prasetyo } \\
\text { Ferdianto \& } \\
\text { Budi } \\
\text { Prihanto, } \\
\text { 2017) }\end{array}$ & $\begin{array}{l}\text { Hubungan } \\
\text { Aktivitas } \\
\text { Fisik Harian } \\
\text { dengan } \\
\text { Tingkat } \\
\text { Kebugaran } \\
\text { Jasmani } \\
\text { (Studi Pada } \\
\text { Siswa Kelas } \\
\text { VIII SMP } \\
\text { Negeri } 2 \\
\text { Candi, } \\
\text { Sidoarjo) }\end{array}$ & $\begin{array}{l}\text { This } \\
\text { research } \\
\text { uses non- } \\
\text { experimental } \\
\text { method with } \\
\text { correlation } \\
\text { design }\end{array}$ & $\begin{array}{l}\text { There is no } \\
\text { significant } \\
\text { relationship } \\
\text { between daily } \\
\text { physical activity } \\
\text { and physical } \\
\text { fitness level. This } \\
\text { can be caused by } \\
\text { other factors that } \\
\text { affect the level of } \\
\text { physical fitness } \\
\text { more. }\end{array}$ \\
\hline 8 & $\begin{array}{l}\text { (Andriyani, } \\
\text { 2017) }\end{array}$ & $\begin{array}{l}\text { Status } \\
\text { Kebugaran } \\
\text { Jasmani } \\
\text { Siswa Putri } \\
\text { Kelas VIII } \\
\text { SMP Negeri e } \\
\text { Depok, } \\
\text { Yogyakarta }\end{array}$ & $\begin{array}{l}\text { descriptive } \\
\text { research } \\
\text { with cross } \\
\text { sectional } \\
\text { design }\end{array}$ & $\begin{array}{l}\text { Based on the } \\
\text { results of data } \\
\text { analysis known } \\
\text { from } 63 \text { female } \\
\text { students, physical } \\
\text { fitness status was } \\
1 \text { student (1.58 } \\
\text { percent) very well, } \\
2 \text { students ( } 3.19 \\
\text { percent) good, } 27 \\
\text { students ( } 42.86 \\
\text { percent) were } \\
\text { moderate, } 32 \\
\text { students (50, } 76 \\
\text { percent) are } \\
\text { lacking, and } 1 \\
\text { student (1.58 } \\
\text { percent) is very } \\
\text { poor. }\end{array}$ \\
\hline 9 & (Darmawan, & Upaya & there is no & Efforts to improve \\
\hline
\end{tabular}

\begin{tabular}{|c|c|c|c|c|}
\hline & 2017) & $\begin{array}{l}\text { Meningkatkan } \\
\text { Kebugaran } \\
\text { Jasmani } \\
\text { Siswa Melalui } \\
\text { Penjas }\end{array}$ & $\begin{array}{l}\text { discussion of } \\
\text { what } \\
\text { methodology } \\
\text { is used in the } \\
\text { article }\end{array}$ & $\begin{array}{l}\text { physical fitness of } \\
\text { students can be } \\
\text { done through } \\
\text { physical } \\
\text { education. Among } \\
\text { others, by utilizing } \\
\text { penjasorkes time } \\
\text { which is } 3 \times 45 \\
\text { minutes a week, } \\
\text { then improving the } \\
\text { strategy of } \\
\text { penjasorkes } \\
\text { teachers in } \\
\text { designing } \\
\text { education. }\end{array}$ \\
\hline 10 & $\begin{array}{l}\text { (Prasetio, } \\
\text { Sutisyana, } \\
\text { \& Ilahi, } \\
\text { 2017) }\end{array}$ & $\begin{array}{l}\text { Tingkat } \\
\text { Kebugaran } \\
\text { Jasmani } \\
\text { Berdasarkan } \\
\text { Indeks Massa } \\
\text { Tubuh pada } \\
\text { Siswa SMP } \\
\text { Negeri 29 } \\
\text { Bengkulu } \\
\text { Utara }\end{array}$ & $\begin{array}{l}\text { qualitative } \\
\text { research }\end{array}$ & $\begin{array}{l}\text { From the data } \\
\text { obtained it is } \\
\text { known that the } \\
\text { higher the value of } \\
\text { the body mass } \\
\text { index the lower } \\
\text { the level of } \\
\text { physical fitness. } \\
\text { This is evidenced } \\
\text { by the absence of } \\
\text { students who have } \\
\text { a body mass index } \\
\text { fat and have a } \\
\text { good level of } \\
\text { physical fitness. }\end{array}$ \\
\hline 11 & $\begin{array}{l}\text { (Apriyano, } \\
2017 \text { ) }\end{array}$ & $\begin{array}{l}\text { Kontribusi } \\
\text { Kebugaran } \\
\text { Jasmani } \\
\text { Terhadap } \\
\text { Hasil Belajar } \\
\text { Pendidikan } \\
\text { Jasmani } \\
\text { Olahraga } \\
\text { Kesehatan } \\
\text { (Penjasorkes) } \\
\text { pada Pelajar } \\
\text { SMP Pertiwi } \\
\text { Siteba Padang }\end{array}$ & $\begin{array}{l}\text { quantitative } \\
\text { approach } \\
\text { method } \\
\text { using } \\
\text { correlation } \\
\text { research }\end{array}$ & $\begin{array}{l}\text { there is a } \\
\text { significant } \\
\text { relationship } \\
\text { between physical } \\
\text { fitness and } \\
\text { physical education } \\
\text { learning outcomes } \\
\text { with a contribution } \\
\text { of } 5.18 \text { percent }\end{array}$ \\
\hline 12 & $\begin{array}{l}\text { (Siwi } \\
\text { Yogantoro } \\
\text { \& T.K, } \\
\text { 2017) }\end{array}$ & $\begin{array}{l}\text { Perbandingan } \\
\text { Tingkat } \\
\text { Kebugaran } \\
\text { Jasmani } \\
\text { Siswa Kelas } \\
\text { VIII di } \\
\text { Sekolah } \\
\text { Menengah } \\
\text { Pertama } \\
\text { Negeri } \\
\text { Dataran } \\
\text { Tinggi dan } \\
\text { Daerah } \\
\text { Pesisir }\end{array}$ & $\begin{array}{l}\text { non- } \\
\text { experimental } \\
\text { research }\end{array}$ & $\begin{array}{l}\text { (1) there is no } \\
\text { difference in } \\
\text { physical fitness } \\
\text { level between } \\
\text { students who live } \\
\text { in high altitude } \\
\text { areas and coastal } \\
\text { areas students. (2) } \\
\text { students in the } \\
\text { highlands have the } \\
\text { same level of } \\
\text { physical fitness } \\
\text { with an average } \\
\text { value of } 13.27 \text { and } \\
\text { students in coastal } \\
\text { areas at } 12.38 \text {. (3) } \\
\text { the two schools in } \\
\text { the highlands and } \\
\text { coastal areas have } \\
\text { the same level of } \\
\text { physical fitness. }\end{array}$ \\
\hline 13 & $\begin{array}{l}\text { (Sepriadi } \\
\text { Zalfendi; } \\
\text { Mardayanti, } \\
\text { Mardayanti, } \\
\text { 2018) }\end{array}$ & $\begin{array}{l}\text { Perbedaan } \\
\text { Tingkat } \\
\text { Kebugaran } \\
\text { Jasmani } \\
\text { Siswa Kelas } \\
\text { Unggul dan } \\
\text { Kelas Reguler } \\
\text { di Sekolah } \\
\text { Menengah } \\
\text { Pertama } \\
\text { Negeri 4 Kota }\end{array}$ & $\begin{array}{l}\text { comparative } \\
\text { research }\end{array}$ & $\begin{array}{l}\text { there is no } \\
\text { significant } \\
\text { difference between } \\
\text { the level of } \\
\text { physical fitness of } \\
\text { the superior class } \\
\text { and the level of } \\
\text { physical fitness of } \\
\text { the regular class }\end{array}$ \\
\hline
\end{tabular}




\begin{tabular}{|c|c|c|c|c|}
\hline & & Pariaman & & \\
\hline 14 & $\begin{array}{l}\text { (Prayoga \& } \\
\text { Barikah, } \\
\text { 2019) }\end{array}$ & $\begin{array}{l}\text { Perbandingan } \\
\text { Tingkat } \\
\text { Kebugaran } \\
\text { Jasmani } \\
\text { Siswa } \\
\text { Sekolah } \\
\text { Menengah } \\
\text { Pertama } \\
\text { Negeri } \\
\text { Dataran } \\
\text { Tinggi dan } \\
\text { Dataran } \\
\text { Rendah } \\
\text { (Daerah } \\
\text { Pesisir) }\end{array}$ & $\begin{array}{l}\text { non- } \\
\text { experimental } \\
\text { research }\end{array}$ & $\begin{array}{l}\text { It is known } \\
\text { together from the } \\
\text { results of research } \\
\text { into how the } \\
\text { physical state of } \\
\text { junior high school } \\
\text { students in the } \\
\text { highlands and in } \\
\text { the lowlands. } \\
\text { From the overall } \\
\text { sample of } \\
\text { highland students } \\
\text { the average level } \\
\text { of physical fitness } \\
\text { was good, while } \\
\text { the lowland area } \\
\text { students had a } \\
\text { level of physical } \\
\text { fitness that was } \\
\text { quite lacking. }\end{array}$ \\
\hline
\end{tabular}

Each article is reviewed and analyzed based on the scale provided in the checklist. From the checklist, the quality of each article can be analyzed in detail and rationally according to important elements of the research team's articles. The table below illustrates and explains the findings obtained from the analysis.

- Article Title \& Abstract

The titles of all articles are clear and understandable. All abstracts of each article are good because they cover the background, goals of the research team, results, and conclusions. From all abstracts of the research team, it is evident that the average level of physical fitness is still not maximal, especially by correlating with several factors.

- The problem of the research team

For this section as a whole from each article that has been read that the problem raised is how the level of physical fitness is very important and what factors influence it, then whether the level of physical fitness effects from the teaching and learning process to the learning outcomes obtained by students. The demands of an increasingly modern era with the digital era can be said to be progress and a setback. Advance in terms of technology but backward in terms of health. Coupled with the many policies in schools and ministries so that physical education subjects are increasingly ignored.

- Objective

All articles have the same goal, which is to know the level of physical fitness. However, there are some basic differences but still, have the same goal. There are 4 articles aimed at looking at relationships and contributions, 3 experimental articles to see influence and effort, 3 articles looking at comparisons and differences on research objects, 3 articles only looking at physical fitness status and 1 article looking at physical fitness status by different methods.

- Operational definition

The whole article discussing for full operational definition in the article is not in the abstract.

- Hypothesis

There are 5 articles that hypothesis is rejected, then 5 article that hypothesis received, and 4 articles only see the status and the conclusions included agree or equal to the accepted hypothesis.

- Literature review

Literature according to the research problem and covers most of the issues are available on the specified topics. the presentation of literature is also in accordance with the keywords of the research title

- Research design

All articles have determined the design correctly and are suitable for answering research questions and most of the user is a quantitative approach with several methods including, experimental, non-experimental, surveying, class action. And only one article which uses a qualitative approach.

- Samples and Sampling Techniques

The sample size is adequate and appropriate sampling method of the population for all articles. However, 4 articles do not explain completely how the sampling technique used.

- Methods and data collection tools

Instrument or other means for data collection adequately explained the reliability and validity of the instrument are handled, data collection methods are described, and mention the benefits and the specific problems faced by the research team with specific data collection method.

- Data Analysis

All articles read to provide a strong explanation of how to analyze data. But there is one article that does not explain well the analysis method used because it uses a qualitative approach but still describes the number of respondents. Overall the process used to analyze data is clear and appropriate to answer the research team's questions, the results table is clear and understandable

- Interpretation and discussion of the data

For all articles selected, they have explained the results of the research team in detail, showing data in accordance with facts. So the results of his research team can be concluded that the level of physical fitness is very influential and needs special attention for students. In order to support daily health, to support the learning process.

- Conclusion and recommendation

All articles conclude the findings in a concise and precise manner describing the most significant findings, conclusions drawn in accordance with the objectives of the research team, hypotheses and practical recommendations made for improvements in practice. This recommendation is consistent with the research team's findings and results. But for recommendations, there are only 4 articles that do not have a hypothesis. And in general, the whole article has a goal to followup.

- Reference

All articles provide a good reference in accordance with some recognized guidelines 


\section{DISCUSSION}

\section{- Summary of Evidence}

The evidence of this research comes from the research team conducted by the research team about how the current level of physical fitness of junior high school students. The research team is based on the benefits of physical fitness levels for students. The research team is based on a research team conducted by another research team that examines how the student's physical fitness level.

- Strengths and limitations of systematic review

Systematic studies make it easy to identify existing problems. In this case, the level of physical fitness is juxtaposed with several supporting factors and comparison factors. Because in the learning process, especially physical education, the definition of fitness must be demonstrated. From the discussion of many articles, it is found that the level of physical fitness greatly affects students both in health and in the learning process, especially physical education learning.

- Evidence Gaps (GAP)

he gap is very visible because physical education as a whole is not compulsory and major in Indonesian education, is not included in determining a student's graduation and is sometimes written off in the list of lessons to give more time to major subjects such as Mathematics, Natural Sciences, Science Social, Indonesian and English.

However, in many observations researchers have found that Physical Education is a complete subject that can help in the main subjects. Then by paying attention to and prioritizing the physical fitness level of a student, it is expected to help the student in health and improve concentration. So that in a healthy body there are physical qualities and mind concentration.

\section{CONCLUSIONS}

The implication of the review of the physical fitness level of students is to increase the potential of students through physiological aspects. So students have the desire to improve physical fitness in order to support their progress in the learning process later. Especially with the advancement of technology, will make students lazier and do not pay attention to their own health. For future research teams, the research team needs to observe problems that affect the level of physical fitness in the learning process. The research team can examine the development of physical activities that can be done in the learning process without taking a long time but has the aim to maintain and improve the physical fitness of students. At present the focus of learning as a general is only focused on the cognitive aspects, so often forget the psychomotor aspects. Because for the achievement of education all aspects must be balanced and mutually supportive between affective, cognitive and psychomotor.

\section{REFERENCES}

[1] Andriyani, F D (2017) STATUS KEBUGARAN JASMANI SISWA PUTRI KELAS VIII SMP N 3 DEPOK YOGYAKARTA. Motion: Journal Research of Physical Education, 8(1), 59-66.
Retrieved

from http://jurnal.unismabekasi.ac.id/index.php/motion/article/view/454

[2] Annas, M. (2011). Hubungan Kesegaran Jasmani, Hemoglobin, Status Gizi, dan Makan Pagi terhadap Prestasi Belajar. Media Ilmu Keolahragaan Indonesia, 1(2). Retrieved from http://journal.unnes.ac.id/nju/index.php/miki/article/view/2034

[3] Apriyano, B. (2017). Kontribusi Kebugaran Jasmani Terhadap Hasil Belajar Pendidikan Jasmani Olahraga Kesehatan (Penjasorkes) pada Pelajar SMP Pertiwi Siteba Padang. Jurnal Menssana, 2(2), 19-26. https://doi.org/https://doi.org/10.24036/jm.v2i2.20

[4] Darmawan, I. (2017). Upaya Meningkatkan Kebugaran Jasman Siswa Melalui Penjas. Jurnal Inspirasi Pendidikan, 7(2), 143-154. https://doi.org/https://doi.org/10.21067/jip.v7i2.1700

[5] Julianto, I. (2016). Upaya Meningkatkan Kebugaran Jasmani Melalui Sirkuit Training Kids pada Siswa. JUARA: Jurnal Olahraga, $1(1), \quad 7-14 . \quad$ Retrieved from http://jurnal.upmk.ac.id/index.php/juara/article/view/56

[6] Naylor, P.-J., Nettlefold, L., Race, D., Hoy, C., Ashe, M. C., Higgins, J. W., \& McKay, H. A. (2015). Implementation of school based physical activity interventions: a systematic review. Preventive Medicine, 72, 95-115.

[7] Prasetio, E., Sutisyana, A., \& Ilahi, B. R. (2017). TINGKAT KEBUGARAN JASMANI BERDASARKAN INDEKS MASSA TUBUH PADA SISWA SMP NEGERI 29 BENGKULU UTARA. Jurnal Ilmiah Pendidikan Jasmani, 1(1), 1-5. Retrieved from https://ejournal.unib.ac.id/index.php/kinestetik/article/view/3470

[8] Prasetyo Ferdianto, T., \& Budi Prihanto, J. (2017). Hubungan Aktivitas Fisik Harian Dengan Tingkat Kebugaran Jasmani (Studi Pada Siswa Kelas VIII SMP Negeri 2 Candi, Sidoarjo). Jurnal Pendidikan Olahraga Dan Kesehatan, 5(3). Retrieved from https://jurnalmahasiswa.unesa.ac.id/index.php/jurnal-pendidikanjasmani/article/download/21677/19870

[9] Prayoga, H. D., \& Barikah, A. (2019). PERBANDINGAN TINGKAT KEBUGARAN JASMANI SISWA SEKOLAH MENENGAH PERTAMA NEGERI DATARAN TINGGI DAN DATARAN RENDAH (DAERAH PESISIR). Riyadhoh: Jurnal Pendidikan Olahraga, 2(1), 14-21. Retrieved from https://ojs.uniska-

bjm.ac.id/index.php/riyadhohjurnal/article/view/2026

[10] Sepriadi Zalfendi; Mardayanti, Mardayanti, S. Z. (2018). PERBEDAAN TINGKAT KEBUGARAN JASMANI SISWA KELAS UNGGUL DAN KELAS REGULER DI SEKOLAH MENENGAH PERTAMA NEGERI 4 KOTA PARIAMAN. Jurnal Sporta Saintika, (Vol 3 No 1 (2018): Jurnal Sporta Saintika Maret), 400-409. https://doi.org/https://doi.org/10.24036/sporta.v3i1.60

[11] Siwi Yogantoro, Z., \& T.K, B. F. (2017). PERBANDINGAN TINGKAT KEBUGARAN JASMANI SISWA KELAS VIII DI SEKOLAH MENENGAH PERTAMA NEGERI DATARAN TINGGI DAN DAERAH PESISIR. Jurnal Pendidikan Olahraga Dan Kesehatan, 4(3). Retrieved from https://jurnalmahasiswa.unesa.ac.id/index.php/jurnal-pendidikanjasmani/article/view/19712

[12] Soewito, N. (2014). Pengaruh Metode Circuit Training Terhadap Kebugaran Jasmani Peserta didik Kelas VII SMP Negeri 1 Jepon, Kabupaten Blora. Malang: Fakultas Ilmu Keolahragaan Universitas Negeri Malang. Retrieved from http://fik.um.ac.id/wpcontent/uploads/2014/11/12.PROCEEDINGS-PERTEMUANILMIAH-ILMU-KEOLAHRAGAAN-NASIONAL-2014MALANG.Ngatman-Soewito-REV.pdf

[13] Sulistiono, A. A. (2014). Kebugaran jasmani siswa pendidikan dasar dan menengah di Jawa Barat. Jurnal Pendidikan Dan Kebudayaan, 20(2), 223-233. Retrieved from http://jurnaldikbud.kemdikbud.go.id/index.php/jpnk/article/view/14 0

[14] Widodo, B. S., \& Kusnanik, N. W. (2013). Tingkat Kesegaran Jasmani pada Siswa SMP Negeri 2 Krembung dan SMP Negeri 2 Sidoarjo. Jurnal Prestasi Olahraga, 1(1). Retrieved from https://jurnalmahasiswa.unesa.ac.id/index.php/jurnal-prestasiolahraga/article/view/2146

[15] Yudi Irianto, F., \& Nurhayati, F. (2013). Hubungan Status Gizi dan Aktivitas Olahraga dengan Tingkat Kebugaran Jasmani (Studi pada Siswa Kelas VIII SMP Negeri 1 Kediri). Jurnal Pendidikan Olahraga Dan Kesehatan, 1(2). Retrieved from https:/ jurnalmahasiswa.unesa.ac.id/index.php/jurnal-pendidikan-jasmani/ article/view/3091 